\title{
Polycrystalline Thin-Film Module and System Performance
}

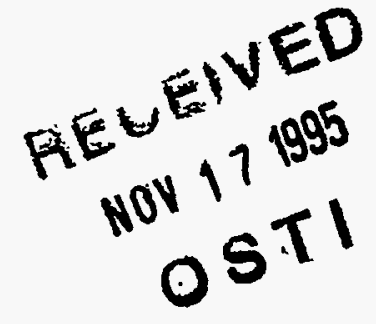

T. Strand, B. Kroposki, R. Hansen,

L. Mrig

Presented at the

PV Performance \& Reliability Workshop

September 7-8, 1995

Golden, Colorado

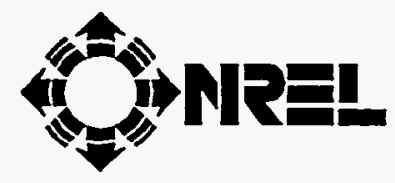

National Renewable Energy Laboratory 1617 Cole Boulevard Golden, Colorado 80401-3393

A national laboratory of the U.S. Department of Energy Managed by Midwest Research Institute for the U.S. Department of Energy under contract No. DE-AC36-83CH10093

Prepared under Task No. PV660103

November 1995 


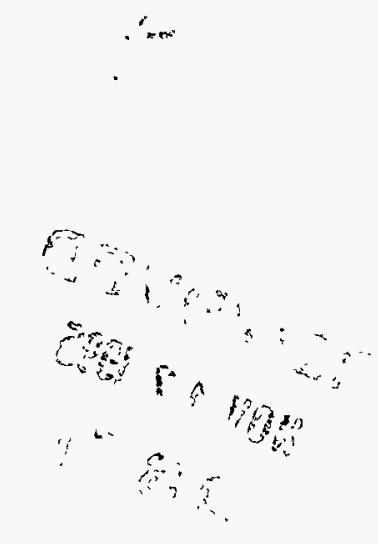

\section{NOTICE}

This report was prepared as an account of work sponsored by an agency of the United States government. Neither the United States govemment nor any agency thereof, nor any of their employees, makes any warranty, express or implied, or assumes any legal liability or responsibility for the accuracy, completeness, or usefulness of any information, apparatus, product, or process disclosed, or represents that its use would not infringe privately owned rights. Reference herein to any specific commercial product, process, or service by trade name, trademark, manufacturer, or otherwise does not necessarily constitute or imply its endorsement, recommendation, or favoring by the United States govemment or any agency thereof. The views and opinions of authors expressed herein do not necessarily state or reflect those of the United States government or any agency thereof.

Available to DOE and DOE contractors from:

Office of Scientific and Technical Information (OSTI)

P.O. Box 62

Oak Ridge, TN 37831

Prices available by calling (615) 576-8401

Available to the public from:

National Technical Information Service (NTIS)

U.S. Department of Commerce

5285 Port Royal Road

Springfield, VA 22161

(703) $487-4650$ 


\title{
Polycrystalline Thin-Film Module and System Performance
}

\author{
Troy Strand, Benjamin Kroposki, Robert Hansen and Laxmi Mrig \\ National Renewable Energy Laboratory \\ 1617 Cole Blvd., Golden, CO 80401, USA
}

\section{INTRODUCTION}

The Module and System Performance and Engineering Project at the National Renewable Energy Laboratory (NREL) conducts in-situ technical evaluations of photovoltaic (PV) modules and systems (arrays). These evaluations on module/array performance and stability are conducted at the NREL Photovoltaic Outdoor Test Facility (OTF) in Golden, CO (See Figure 1). The modules and arrays are located at $39.7^{\circ} \mathrm{N}$ latitude, $105.2^{\circ} \mathrm{W}$ longitude, and at 1,782 meters elevation.

Currently, two polycrystalline thin-film technologies are the focus of the research presented here. The module structures are copper indium diselenide (CIS) from Siemens Solar Industries and cadmium telluride (CdTe) from Solar Cells, Inc. The research team is attempting to correlate individual module performance with array performance for these two polycrystalline thin-film technologies. This is done by looking at module and array performance over time. Also, temperature coefficients are determined at both the module and array level.

\section{EXPERIMENTAL PROCEDURE}

Long-term performance data is acquired on individual modules using a Raydec RD-1200* multitracer and on arrays using a Daystar* currentversus-voltage (I-V) curve tracer as well as Campbell Scientific* dataloggers. Individual module and system data is then compared for correlation. It should be noted that, because these are research modules, they do not all come from a common process or production stream and this fact may be the source of some variation in the data. Therefore, the temperature coefficients presented in this paper are preliminary for these technologies.

\section{Individual Module Data Acquisition}

Individual module performance is monitored with a RD-1200 multi-tracer. The multi-tracer is capable of testing up to 15 individual modules. For this experiment, the modules are loaded at their maximum power (max-power) point except when I-V curves are taken. I-V curves are swept from $I_{s c}$ to $\mathrm{V}_{\text {oc }}$ and are acquired every half hour at irradiances of $950-1050 \mathrm{~W} / \mathrm{m}^{2}$. Data were collected over a period of approximately 1 year for this test.

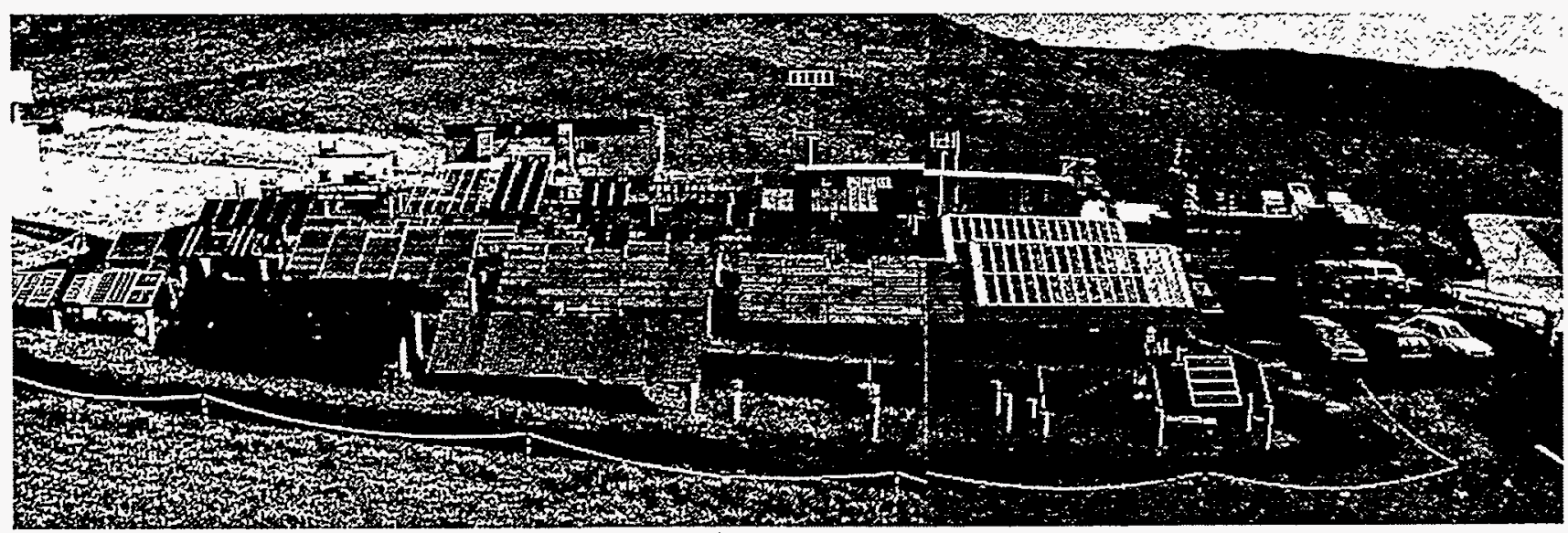

Figure 1. NREL Photovoltaic Outdoor Test Facility

* Reference to a specific manufacturer's product does not constitute an endorsement by the Department of Energy or NREL, but refers to products that are representative of instruments used for the purposes described in this text. 
Array/System Data Acquisition

To monitor and evaluate system performance, two sets of data are collected. The two data sets include instantaneous measurements and long-term data acquisition.

The instantaneous array performance is monitored via a portable $I-V$ curve tracer. These $I-V$ traces are acquired once a month (weather permitting) at planeof-array (POA) irradiances between 900 and 1100 $\mathrm{W} / \mathrm{m}^{2}$.

Long term array/system performance is monitored via a Campbell Scientific CR10 datalogger. Data collected include array current and voltage, back-ofmodule and ambient temperatures, and POA irradiance. Data are sampled every $5 \mathrm{~s}$ and are stored as $15-\mathrm{min}$ averages.

\section{RESULTS AND DISCUSSION}

\section{Siemens Solar Industries CIS Modules}

\section{Siemens Solar CIS Module Performance}

One Siemens Solar CIS module was used for the module data. This module is from a process or production stream similar to the system modules. All modules underwent the same thermal-cycling procedure prior to deployment. The module was installed at a $40^{\circ}$ tilt and is loaded at maximum power during the day, except when I-V curves are taken. Data collection for this study started on July 11,1994 , and ended on June 1, 1995. Figure 2 shows that the CIS modules show a strong inverse correlation of $P_{\max }$ with back-of-module temperature. This effect can be attributed to the narrower band gap of the CIS material. Gaps in the data occur where the multi-tracer was unavailable while being used for other experiments.

To examine the long-term stability of this module, we corrected the data to a constant temperature. For comparative purposes, $25^{\circ} \mathrm{C}$ was chosen. To correct the performance data to $25^{\circ} \mathrm{C}$, a temperature coefficient for the module was calculated. Using a linear regression of power (normalized to 1000 $\mathrm{W} / \mathrm{m}^{2}$ ) versus back-of-module temperature, a temperature coefficient can be calculated (Figure 3). The temperature coefficient of $-0.672 \%{ }^{\circ} \mathrm{C}$ is consistent with previously reported results for the CIS material [1]: Based on this value, the module was calculated to have a $\mathrm{P}_{\max }$ rating at $25^{\circ} \mathrm{C}$ of 29.7W. Figure 4 shows $P_{\max }$ corrected to $25^{\circ} \mathrm{C}$ versus time for the CIS module. From this figure, note that the module shows good stability over time.

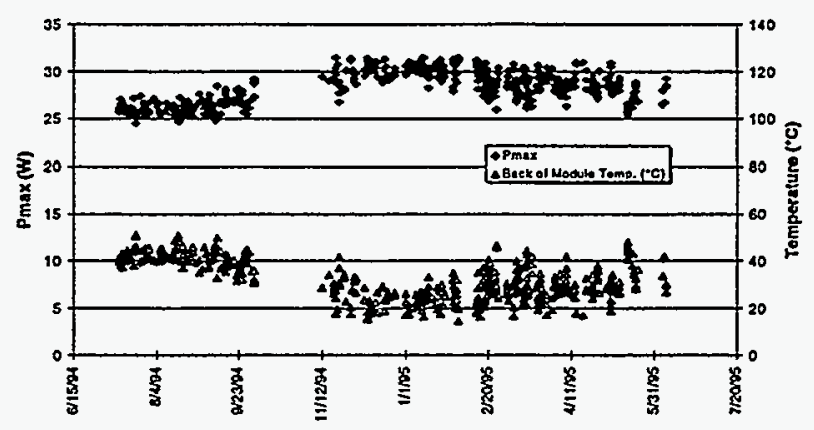

Figure 2. Normalized power and module temperature versus time

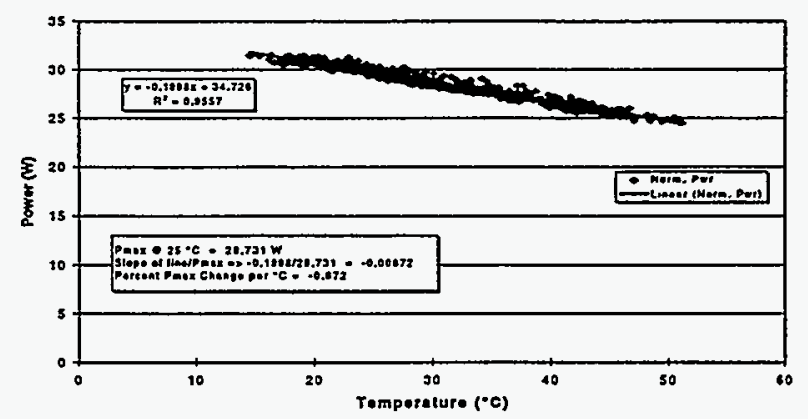

Figure 3. Normalized power versus module temperature

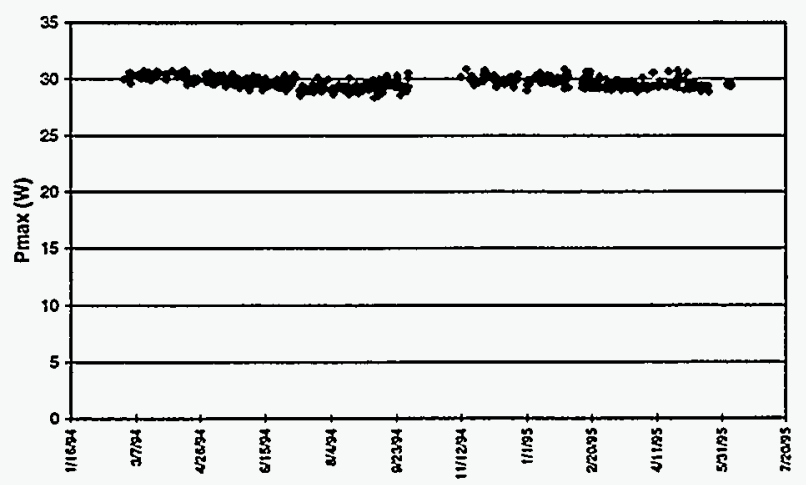

Figure 4. Normalized and temperature-corrected power versus time

Siemens Solar CIS System/Array Performance

The Siemens Solar CIS array is comprised of 34 modules. The array is located at NREL's PV Outdoor Test Facility. All modules were subjected to accelerated testing at Siemens prior to deployment at 
NREL. Each module has an aperture area of 3946.3 $\mathrm{cm}^{2}(127.3$ by $31.0 \mathrm{~cm})$. The average module from this group had the following electrical characteristics (measured at NREL prior to deployment): $P_{\max }=28.3$ $\mathrm{W}, \mathrm{V}_{\max }=15.56 \mathrm{~V}, \mathrm{~V}_{\mathrm{oc}}=22.38 \mathrm{~V}, \mathrm{I}_{\max }=1.832 \mathrm{~A}$, and $\mathrm{I}_{\mathrm{sc}}=2.264 \mathrm{~A}$. Using the average max-power, the summation of module max-powers at standard test conditions (STC) is $962 \mathrm{~W}$.

These modules are vintage CIS modules and do not represent the current state-of-the-art for Siemens Solar. The array is fixed at a $40^{\circ}$ tilt and is aligned true south. The array is divided into three separate subarrays. Two of the subarrays are composed of six parallel strings of two modules in series, and the remaining subarray is composed of five parallel strings of two modules in series. Each subarray feeds dc power to a separate max-power tracker. The output of each max-power tracker is paralleled and tied to a $0.95 \mathrm{ohm}, 2-\mathrm{kW}$ fixed resistive load.

Array installation was completed on September 15, 1993. From then until March 21, 1994, each module's output was shorted. Data acquisition then began on April 1, 1994. Data continues to be acquired without anomaly.

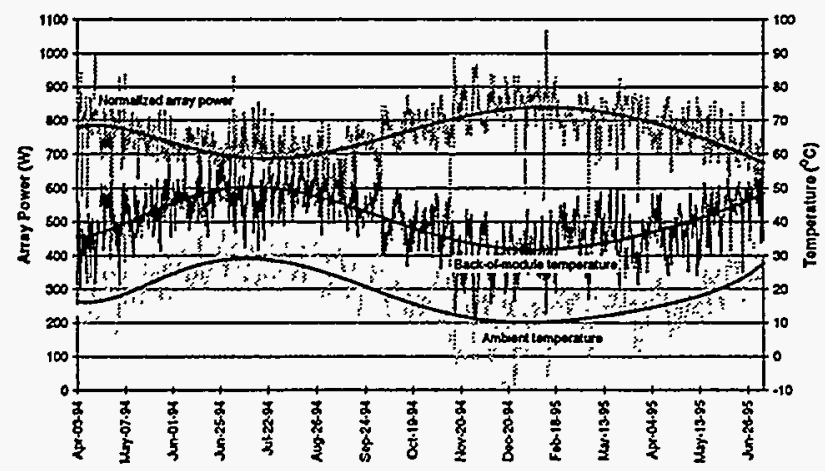

Figure 5. Normalized array power, back-of-module temperature, and ambient temperature versus time

Figure 5 shows array power, back-of-module temperature, and ambient temperature versus time. The data in this chart were restricted to POA irradiances greater than $850 \mathrm{~W} / \mathrm{m}^{2}$. Array power is normalized to $1000 \mathrm{~W} / \mathrm{m}^{2}$. To establish any visual trends, each data series was fit with a $6^{\text {th }}$ order polynomial trend line. The figure shows a strong inverse correlation between array power and backof-module temperature.
Siemens Solar CIS Array Temperature Coefficients The array performance is monitored via a portable $\mathrm{I}-\mathrm{V}$ curve tracer. $\mathrm{I}-\mathrm{V}$ traces are acquired once a month (weather permitting) at POA irradiances between 900 and $1100 \mathrm{~W} / \mathrm{m}^{2}$. Based on this data set, a preliminary temperature coefficient for $P_{\max }$ was calculated. The data were not corrected for spectral effects. Thus, this preliminary coefficient may be influenced by spectrum. Figure 6 presents the temperature coefficient derivation for $P_{\max }$. This was calculated by performing a first-order regression analysis of $P_{\max }$ (normalized to $1000 \mathrm{~W} / \mathrm{m}^{2}$ ) versus back-of-module temperature. The temperature coefficient for $\mathrm{P}_{\max }$ was determined to be $-0.845 \% /{ }^{\circ} \mathrm{C}$ with a $R^{2}$ of 0.91 . This $R^{2}$ indicates that $P_{\max }$ is well correlated with temperature.

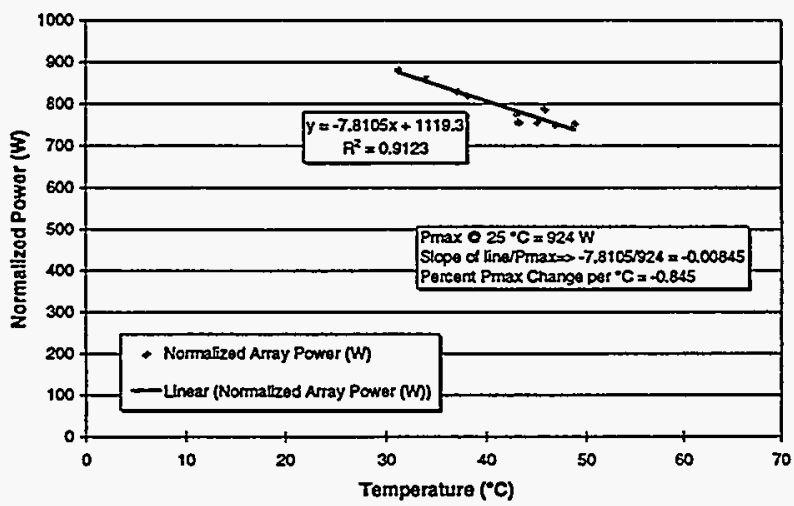

Figure 6. Array $\mathrm{P}_{\max }$ temperature coefficient derivation

The array power presented in figure 5 was corrected for temperature based on the temperature coefficient of $-0.845 \% /{ }^{\circ} \mathrm{C}$. The array performance, normalized to $1000 \mathrm{~W} / \mathrm{m}^{2}$ and corrected to $25^{\circ} \mathrm{C}$ back-ofmodule temperature, is shown in Figure 7. Figure 7 highlights two system performance anomalies.

From late August 1994 to late September 1994, a ground path between each max-power tracker was found. As these particular max-power trackers switch the negative input from the array, a loss in power was experienced. The increase in output seen from December 1994 to April 1995 is due to a failed max-power tracker. The failed max-power tracker was bypassed by tying the subarray directly to the resistive load. Therefore, at or near onesun, the subarray was well matched to the fixed resistive load. Conversely, at lower irradiance levels, the array output would not be well matched to the load and a loss in power would be seen. Neglecting the 
aforementioned max-power tracker anomalies, the temperature-corrected array power is relatively stable with only slight fluctuations that still inversely trend temperature.

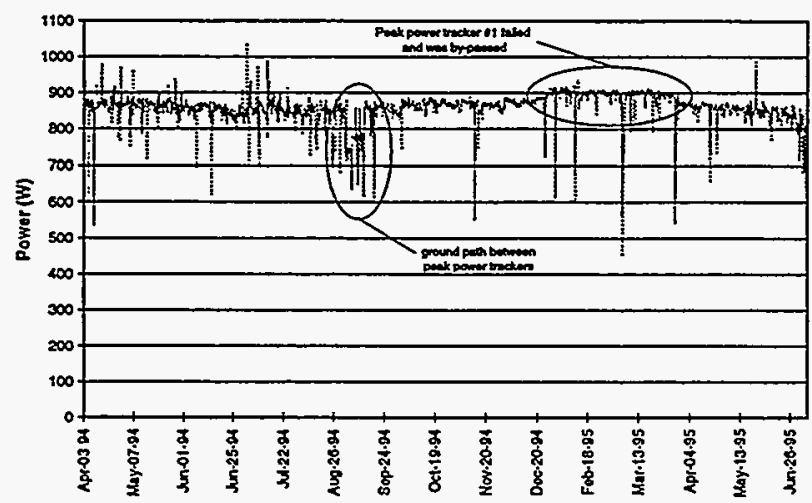

Figure 7. Normalized and temperature-corrected array power versus time

\section{Solar Cells, Inc. CdTe Modules}

\section{Solar Cells, Inc. CdTe Module Performance}

One CdTe module from Solar Cells, Inc., was used for the module performance analysis. This module is from a similar process or production stream as the system modules. The module was installed at a $40^{\circ}$ tilt and is loaded at maximum power during the day, except when I-V curves are taken. Data collection for this experiment started June 1, 1994, and ended June 1, 1995. Figure 8 shows that the CdTe modules show a weak inverse correlation between $\mathrm{P}_{\max }$ and the back-of-module temperature. This effect can be attributed to the wider band gap of the CdTe material as compared to CIS. Gaps in the data occur where the multi-tracer was being used for other experiments.

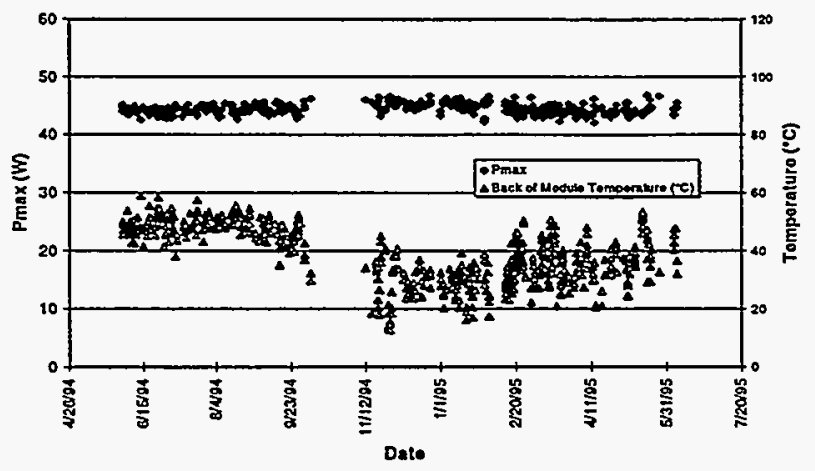

Figure 8. Normalized power and module temperature versus time
To correct the performance data to $25^{\circ} \mathrm{C}$, a temperature coefficient for the module was calculated. Using a linear regression of power (normalized to $1000 \mathrm{~W} / \mathrm{m}^{2}$ ) versus back-of-module temperature, a temperature coefficient was calculated (Figure 9). The temperature coefficient was calculated to be $-0.217 \% /{ }^{\circ} \mathrm{C}$. This temperature coefficient had an $\mathrm{R}^{2}$ of 0.4 , which means that the data contain considerable scatter. This module was calculated to have a $\mathrm{P}_{\max }$ rating at $25^{\circ} \mathrm{C}$ of $46.6 \mathrm{~W}$.

Figure 10 shows the $P_{\max }$ data of Figure 9 corrected to $25^{\circ} \mathrm{C}$. The figure shows that this module had good stability over the test period.

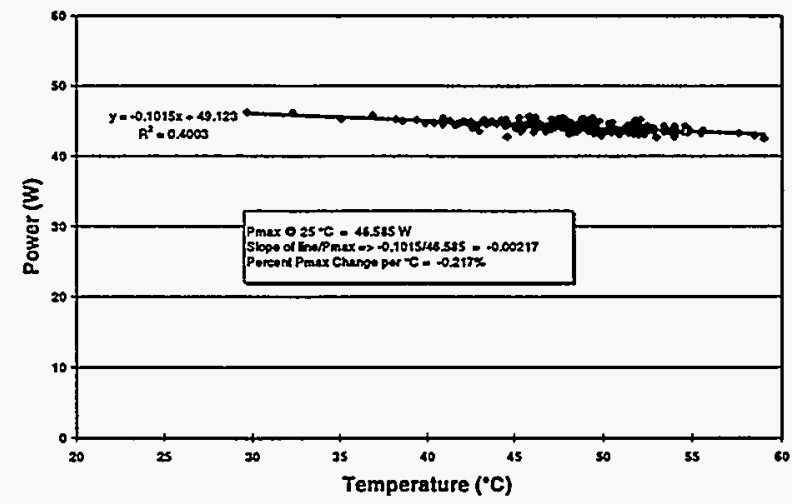

Figure 9. Normalized power versus module temperature

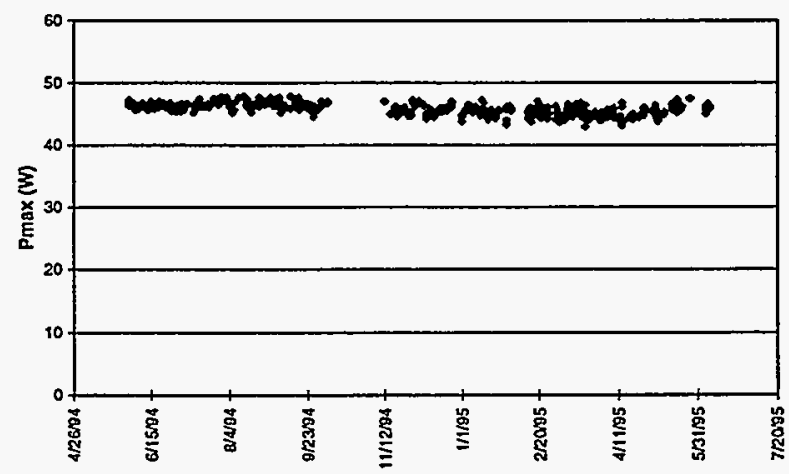

Figure 10. Normalized and temperature-corrected power versus time

Solar Cells, Inc. CdTe System/Array Performance On June 21, 1994, eight SCI CdTe PV modules were integrated into a utility-interconnect PV system at NREL for test and evaluation. The PV array comprises two monopoles. Each monopole employs four series-connected SCI PV modules. The average 
module from this group had the following electrical characteristics (measured at NREL prior to deployment): $51 \mathrm{~W}_{\max }, 89 \mathrm{~V}_{\text {oc }}, 0.93 \mathrm{~A}_{\mathrm{sc}}, 65 \mathrm{~V}_{\max }$, and $0.79 \mathrm{~A}_{\max }$. The module's aperture area is $0.68 \mathrm{~m}^{2}$ $(57.7$ by $117.7 \mathrm{~cm})$. The array is fixed at a $30^{\circ}$ tilt angle. The summation of module max-powers (as measured by NREL) was approximately $400 \mathrm{~W}_{\mathrm{dc}}$. Thus, the system was labeled the SCI $400 \mathrm{~W}_{\mathrm{de}} \mathrm{PV}$ array. The array was operated at its max-power point by an Omnion series 2200 inverter. The output of the Omnion inverter was fed to the local utility's power distribution grid. The modules were deployed in intervals beginning in February 1994 and ending in May 1994. System operation began June 21, 1994. Data acquisition commenced on July 7, 1994.

The $400 \mathrm{~W}_{\mathrm{dc}}$ array was decommissioned on June 19 , 1995 , and was replaced with 24 newer modules that incorporate SCI's frameless mount and a wire pigtail in place of the terminal block and junction box. This paper discusses only the performance of the $400 \mathrm{~W}_{\mathrm{dc}}$ array over the 1-year test period.

Figure 11 shows dc power, ac power, back-of-module temperature, and ambient temperature versus time for the $400 \mathrm{~W}_{\mathrm{dc}}$ array. The data are fit with $6^{\text {th }}$ order polynomial trend lines to aid visually in establishing any trends. The data used in the figure were restricted to POA irradiance greater than $850 \mathrm{~W} / \mathrm{m}^{2}$. $\mathrm{Dc}$ and ac power were normalized to $1000 \mathrm{~W} / \mathrm{m}^{2}$ for the figure. The back-of-module temperature ran at an average of $26^{\circ} \mathrm{C}$ above the ambient. This figure shows that temperature had little effect on ac power output at or near one-sun. However, dc power shows a weak inverse correlation with temperature. This discrepancy is possibly due to the low input level at which the $400 \mathrm{~W}_{\mathrm{dc}}$ array operated the $2 \mathrm{~kW}_{\mathrm{ac}}$ Omnion inverter. The figure further shows that array/system performance were relatively stable over this test period.

Based on the monthly CdTe I-V curve trace results, a preliminary temperature coefficient for $\mathrm{P}_{\max }$ was calculated. The coefficient was obtained through a first order regression analysis and was calculated to be $-0.265 \% /{ }^{\circ} \mathrm{C}$ and $-0.236 \% /{ }^{\circ} \mathrm{C}$ for the positive and negative monopoles, respectively. The corresponding $R^{2}$ values for these coefficients are 0.64 and 0.79 . These $R^{2}$ values indicate that the $P_{\max }$ temperature coefficients explain about $70 \%$ of the variation in $P_{\max }$ due to temperature. To simplify this analysis, the two temperature coefficients were averaged, that is, $\left((-0.265+-0.236) / 2=-0.25 \% /{ }^{\circ} \mathrm{C}\right)$.

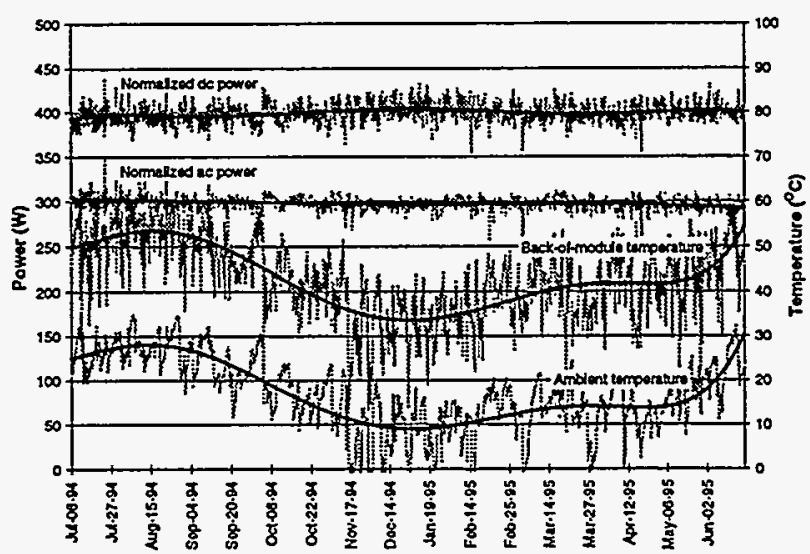

Figure 11. Normalized ac and dc power versus time

Figure 12 shows dc power corrected for temperature and normalized to $1000 \mathrm{~W} / \mathrm{m}^{2}$ versus time for the 400 $\mathrm{W}_{\mathrm{dc}}$ array. For comparison, the normalized $\mathrm{dc}$ power (not corrected for temperature) is also included in the chart. The temperature coefficient used was $-0.25 \% /{ }^{\circ} \mathrm{C}$, the average between the positive and negative monopoles. The data used in the figure were restricted to POA irradiance greater than $850 \mathrm{~W} / \mathrm{m}^{2}$. Note that the temperature coefficient used slightly reduces the variation in $\mathrm{P}_{\max }$ caused by temperature.

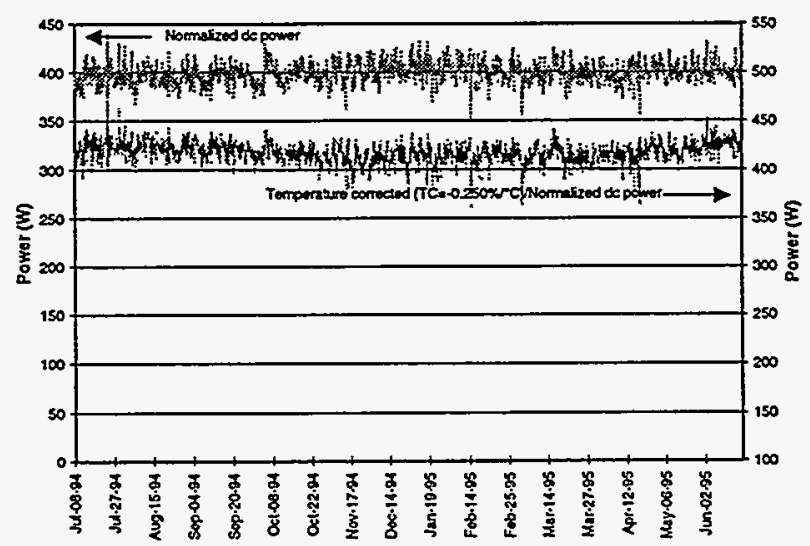

Figure 12. Normalized and temperature-corrected dc power compared to the normalized dc power

\section{CONCLUSIONS}

Preliminary temperature coefficients for $\mathrm{P}_{\max }$ for both polycrystalline technologies at the module and array level were calculated. Table 1 summarizes these results. The data were not corrected for spectral 
effects, thus, these preliminary coefficients may be influenced by spectrum.

Correlation of CIS Module and System Data

A strong inverse correlation between array power and back-of-module temperature was shown to exist at both the module and array levels. This is mainly due to the narrow band gap of the CIS material, which results in a strong inverse correlation between voltage and temperature. The temperature-corrected module and array powers were shown to be relatively stable over the one year test period.

Preliminary temperature coefficients for $P_{\max }$ at the module and array level were calculated. The temperature coefficient obtained at the array level is greater than that for the module. This is attributable to several factors, e.g., temperature sensor location, module (elevated) versus array (ground level) location, and variations in the process or production stream.

\section{Correlation of CdTe Module and System Data}

Temperature was shown to have little effect on maxpower at both the module and array level. Both module and array/system performance were relatively stable over the test period.

Preliminary temperature coefficients for $\mathrm{P}_{\max }$ at the module and array level were calculated. Given the low $\mathrm{R}^{2}$ obtained for the module's $\mathrm{P}_{\max }$ temperature coefficient, the corresponding temperature coefficients are considerably more uncertain. The temperature coefficient obtained at the array level was found to be marginally acceptable.

Table 1. Preliminary peak power temperature coefficients

\begin{tabular}{|l|l|l|l|}
\hline Structure & Device & $\begin{array}{l}\text { Max-Power } \\
\text { Temp. Coeff }\end{array}$ & $\mathbf{R}^{2}$ \\
\hline $\mathrm{CIS}$ & Module & $-0.672 \% /{ }^{\circ} \mathrm{C}$ & 0.9 \\
\hline $\mathrm{CIS}$ & Array & $-0.845 \% /{ }^{\circ} \mathrm{C}$ & 0.91 \\
\hline & & & \\
\hline $\mathrm{CdTe}$ & Module & $-0.217 \% /{ }^{\circ} \mathrm{C}$ & 0.4 \\
\hline $\mathrm{CdTe}$ & Array & $-0.25 \% /{ }^{\circ} \mathrm{C}$ & $0.64 / 0.79$ \\
\hline
\end{tabular}

\section{FUTURE WORK}

The Photovoltaic Module and Systems Performance and Engineering Project at NREL will continue to investigate the issues affecting polycrystalline thinfilm module and array performance and stability. This will include in-depth performance versus temperature studies and module versus array/system performance.

\section{ACKNOWLEDGMENTS}

The authors thank Richard DeBlasio for his support of this work. The authors also thank Yehoshua Caiyam, Larry Ottoson, Steve Rummel, and Keith Emery for their help with module measurements and characterization and Joe Burdick for his technical support. Finally the authors would like to thank Siemens Solar Industries and Solar Cells, Inc., for samples and support of this work. This work was supported by the U.S. Department of Energy under contract No. DE-AC36-83CH10093.

\section{REFERENCES}

1. Kroposki, B and L. Mrig, "Thin-Film Module Stability Testing at NREL," NREL Performance and Reliability Workshop, Lakewood, CO, 1994. 